\title{
ADDITIONAL NOTE ON FORESTRY EDUCATION IN U. S. S. R.
}

\author{
By Henry I. Baldwin, Ph.D.
}

Pennsylvania State Forest School

$\mathrm{N}$ a recent article in the Forestry Chronicle (1) Dr. P. M. Barr has given prominence to a note (2) by Dr. Ivar Faludi, which I abstracted a few years ago for Biological Abstracts (3). In my abstract I mentioned among others the course in "forest strategy." This apparently has aroused so much interest and comment, that I have recently investigated the matter, and am informed that such a course, if it ever existed, is not included since the reorganization of the forest school in 1930. Dr. Ivar Faludi, the author of the original note could not be located, having left Sweden shortly after the publication of the article. I am indebted to a friend who visited the school in 1930 after the reorganization, and made notes on the spot, as well as to information received by letter from friends in Sweden, Finland and Germany for the information presented here.

The Forest Institute in Leningrad, founded in 1803, was reorganized in 1925 by combining a number of different institutions under the title of "Less. noj Institut" (meaning "Forest Institute"). In 1930 it was again reorganized and the name changed to "Ljesotechniczeskaja akademia," following a regulation promulgated in 1929 changing the school from a "forest institute" to a "forest-technical academy."

The present organization comprises four main departments: (1) Silviculture (Ljesokhoziaistvennyi fakultet), (2) Forest Economics (Ljesoekonomiczeskii fakultet), (3) Forest Technology (Ljesotechnologiczeskii fakultet) with two divisions, (a) Forest Mechanics (Ljesomechaniczeckoje otdjelenie) and (b) Forest Chemistry (Ljesochimiczeckoje otdjelenie) and (4) Forest Engineering (Ljesoinzhenjernyi fakultet).

The scientific staff of the academy numbers between 200 and 300 persons. The Director is Prof. A. I. Schulz and the Prorektor Nikolas Kobranoff. There were (in 1930) about 3,000 students of whom 1,400 were specializing in silviculture. About 1,000 are graduated annually, of whom one-half have specialized in silviculture. In 1930-31, 1,350 students were to be admitted, 340 to the silviculture division, 280 to economics, 300 to forest technology, 180 to wood chemistry and 250 to forest engineering courses respectively. The

(1) Forest Education in U. S. S. R. For. Chron. 6 (3) : 147-148, 1930.

(2) Faludi, I. Lessnoj Institut. Skogen 15 (23) : 615, 1928. (Incorrectly cited as "vol. 23, 1929" by Barr)

(3) Biological Abstracts $3(7-8): 1440,1929,14,171$. 
school has a budget of $1,200,000$ rubles annually, of which 700,000 rubles is supplied by income from school forests. In addition 2,000,000 rubles are appropriated for research activities. Construction of a new building to cost about $5,000,000$ has just been started.

The new academy maintains close connection with the Institute of Applied Botany, of which Prof. Vavilov is director. Prorektor Kobranoff is also head of the Department of Naturalization in this institute and is particularly interested in the question of origin of tree seed, and forest genetics. This institute carries on a varied program of botanical and agricultural research and had a budget of $4,000,000$ rubles in 1930, with an expected increase to $7,000,000$ in 1931. The staff consists of 900 persons. The salaries paid independent workers range up to 500 rubles and assistants 200 rubles, per month.

The institute possesses immense collections brought together by expeditions sent to all parts of the world for that purpose. Notable among these are seeds of different strains of cultivated plants (27,000 kinds of wheat!) for use in plant breeding.

Foresters are trained also at the Timiriazeff Academy outside of Moscow, and at schools in Arkangelsk, Saratov, Kiew, Charkow, Tillis, Vladivostok, Omsk, Novo-Tscherkask and Gorigord.

I am indebted to Mr. A. Koroleff for the following translation of a pamphlet in Russian issued by the Director of the Forest Technical Academy in 1930 describing the new academy at Leningrad:

\section{Forest Technical ACAdemy}

This Academy, before its re-organization in 1929, was known as the Leningrad Forest Institute. The aim is as follows:

The Academy is a superior institution for instruction and for scientific work, to produce engineers for organizing our forestry and forest industries in order (A) to provide continuously and according to plan, timber and its various products; (B) to organize on socialistic basis business inter-relations in forestry and wood-using industries organizations; $(C)$ to increase the efficiency from material and social points of view in utilization of the govern. ment forest resources.

Besides the engineers for conducting work on production, the Academy trains some of its best graduates for educational, scientific and research activities. Graduates, according to a certain plan, are given frst opportunities for positions in forest "trests" for work (A) in the mills; (B) forest offices; (C) organization of forests and improvements; (D) timber export organizations; and (E) planning of forest management and wood-using industries.

The Academy has four divisions: (1) Forestry, and (2) Forest Economy, with tuition period of $2 \frac{1}{2}$ years, also (3) Forest Technology, and (4) Forest 
Engineering, with 4 years' tuition periods. Shortly a division of Timber Chemistry will be established.

(1) The Forestry Division is sub-divided into three branches: (A) forest management: (a) forest organization (b) forest exploitation; (B) forest growing: (a) growing of forests (b) forest agricultural improvements (c) forest protection (d) horticulture; (C) game.

(2) The Forest Economic Division is sub-divided: (A) Planning of wood supply; (B) planning of forest industries; (C) timber export; (D) internal trade in timber; and $(E)$ co-operation of forest industries.

(3) Division of Forest Technology is sub-divided as follows: (A) mechanical sub-division which covers: (a) saw milling (b) box manufacturing (c) planing (d) standard building parts (e) excelsior; (B) veneer; (a) veneer (b) match manufacturing; $(C)$ carpentering which covers: (a) furniture (b) carpentry building (c) railroad cars (d) agricultural machinery (e) aviation (f) musical instruments; (D) vehicles and others: (a) vehicles (b) turnery (c) conperage (d) bent furniture.

Division of Chemistry of Wood covers: (A) wood distillation: (a) rosinturpentine (b) dry distillation; (B) pulp and paper industry: (a) wood pulp (b) cellulose (c) paper; (C) chemical wood technology: (a) viscose (b) plastic masses (c) extracts (d) timber preservation.

(4) Division of Forest Engineering: (A) logging and mechanization of land transport; (B) river improvements and water transportation; (C) forest improvements; (D) peat sub-division: (a) exploitation of peat (b) peat technology.

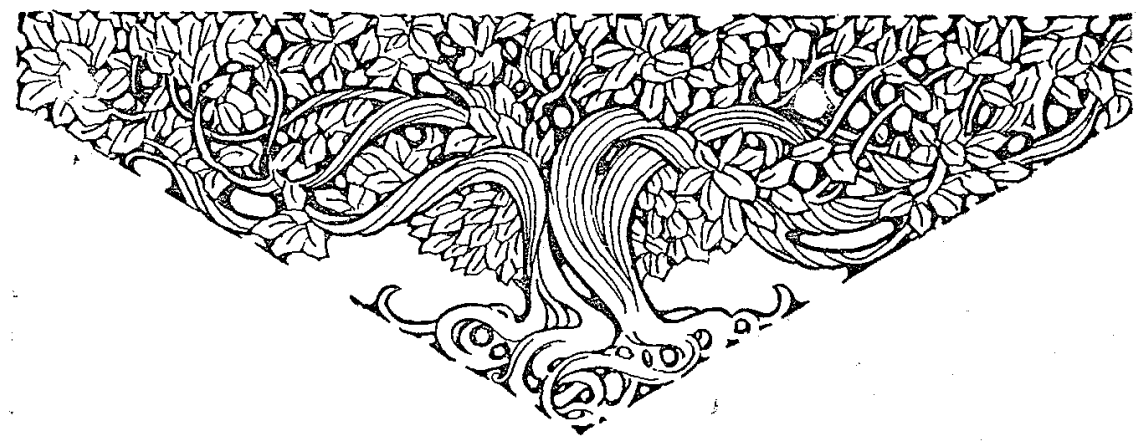

